\title{
The Relationship Study of Perceived Over qualification and Knowledge Sharing on Team Performance
}

\author{
Luo-Na ZHANG \\ Center for Industrial Policy and Management Research, \\ Wuhan University of Science and Technology \\ Wuhan, China \\ E-mail:1169378018@qq.com
}

\author{
Yan CAO \\ Center for Industrial Policy and Management Research, \\ Wuhan University of Science and Technology \\ Wuhan, China \\ E-mail:791845658@qq.com
}

\author{
Yun-Mei LI \\ Center for Industrial Policy and Management Research, \\ Wuhan University of Science and Technology \\ Wuhan, China \\ E-mail:1ymwust@163.com
}

\begin{abstract}
From the management practice and research status of perceived overqualification, knowledge sharing is introduced as an intermediary variable, this paper construct a theoretical model of perceived overqualification, knowledge sharing and team performance, focusing on the effect of employee perceived overqualified on team performance, aims to uncover the "black-box" mechanism of perceived overqualified affect team performance.Through empirical analysis found that (1) perceived overqualification positively influences task performance of the teams, (2) perceived overqualification does not obviously influence growing performance of the teams, (3) perceived overqualification positively influences knowledge sharing of the teams, and (4) knowledge sharing partially mediates the effects of perceived overqualification on team task performance. Therefore, the enterprises should hold a thorough understanding of positive and negative effects of perceived overqualification. Finally, it is suggested that enterprises take appropriate human resources approaches to promote knowledge sharing and team performance.
\end{abstract}

Keywords-Perceived overqualification; Knowledge sharing; Team performance

\section{INTRODUCTION}

The number of graduates in Colleges and universities youth employment groups continued to increase, leading to employment situation is very serious, highly educated workforce in the employment competition can only reduce their employment standards, to engage in those than they actually have the education level and experience to low jobs. This phenomenon is called "excessive qualification" (Overqualification)". With the simultaneous expansion of institutions of higher learning and various training institutions, the choice of enterprises in recruitment becomes larger, recruitment threshold will be higher. Many enterprises in the post qualification frequently require undergraduate, master or even doctoral degree, the demand for academic qualifications has been repeatedly enlarged. Some job recruitment, originally simple and easy to operate types of work, but requires candidates have three or more than five years of relevant experience, which often result in the enterprise qualification is too high, talent waste phenomenon.

Beginning in 1990s, the team was able to work together with team members to create team performance that was greater than team member performance. It was recognized in enterprise management and gradually became popular around the world. In some famous foreign companies, such as Ge Corp, Att Corporation, HP and other well-known international enterprises, the team has become its main form of operation. So, in a team work as the main form of today, we should not be confined to the individual's work performance in talking about the performance, and to consider the integration of the joint efforts of each team member of team performance. High qualified employees by virtue of its excellent level of education and experience, and the other members of the team interaction and fusion process, take the initiative to build around the working environment, expanding the work limits itself, their dominant and invisible skills and knowledge to other team members, so as to enhance team performance. Since then, the question we have been able to address can be summed up as whether there is a relationship between excessive intelligence, perception and team performance What is the mechanism of action between them? This is the content of this paper.

\section{THEORY AND HYPOTHESIS}

\section{A. The Relationship between Perceived Over qualification and Team Performance}

Maynard et al.(2006) found that perceived overqualification negatively affected perceived commitment [1]. Luksyte et al (2011) found that the graduates have participated in the work of the investigation, if employees feel overqualified, dissatisfaction and pressure, boredom and other negative emotions and appear because of their own capacity is not fully utilized, will lead to counterproductive 
work behavior [2]. The results of Bolino \& Feldman (2000) show that the higher the perception is, the worse the subjective performance is. On the other hand, in the face of the same task, aptitude is too high, perceiving the higher ability and experience that employees possess can help them perform better [3]. In the study of Holtom, Lee and Tidd (2002), the quality of perceived employees was better than that of the average employee when evaluated by a supervisor or colleague [4]. Erdogan and Bauer (2009) found in Turkey to carry out research on the frontline sales staff, staff qualification high positive predictive sales performance, namely the recruitment of staff will be directly perceived overqualified for the company's financial benefit [5]. Liu Ruirui (2011) the results of the study show that perceived overqualified had significant positive effect on task performance, a very significant impact on the perception of task performance does not match the influence of development of perception of task performance is not significant [6]. Based on this, the hypothesis is as follows:

H1a: Perceived overqualification has a significant positive impact on team task performance.

H1b: Perceived overqualification has a significant positive impact on team growth performance.

\section{B. The Relationship between Perceived Over qualification and Knowledge Sharing}

Although the knowledge staff high qualifications have not been reuse in the organization can not fully play, but for the need to demonstrate their value, perceived overqualified employees still showed more than the ability to adapt to knowledge sharing behavior, in order to maximize its own advantages. To share knowledge and skills with others or organizations and translate them into organizational achievements, in a sense, is both a affirmation of their own value and a source of motivation. Therefore, this paper argues that individuals who are too perceptive are more likely to share their knowledge with others and assume the following:

$\mathrm{H} 2$ : Perceived overqualification has a significant positive impact on knowledge sharing.

\section{The Relationship between Knowledge Sharing and Team Performance}

Stephen believes that enterprises can create and protect unique knowledge of enterprises to gain competitive advantage. Tsai in 2000 for the thirty-six institutions to do empirical research, pointed out in a multi business unit within the organization, through the public sector can provide learning, mutual learning and cooperation opportunities, and thus stimulate the innovation of knowledge and enhance innovation ability. Kearns and Lederer put forward the organization between the internal $\mathrm{CEO}$ and CIO frequently in their respective fields of mutual knowledge circulation, help to improve the organization and create competitive advantage for the Srivasta et A1 in the study of decentralization leadership, knowledge sharing, team effectiveness and team performance that team knowledge sharing on team performance have a significant impact. Therefore, the hypothesis is as follows:
H3a: knowledge sharing has a significant positive impact on team task performance.

$\mathrm{H} 3 \mathrm{~b}$ : knowledge sharing has a significant positive impact on team growth performance.

\section{The Mediating Role of Knowledge Sharing}

In recent years, the research team of scholars gradually formed "the context of the IPO research input process output, input refers to the team put into operation the advantageous resources and environment, is the process of combining ability and mechanism of team knowledge, team performance and output. Li Xianan (2013) introduced knowledge sharing as a mediating variable in the study of the relationship between knowledge differences and team performance [7]. Therefore, the following assumptions are made:

H4a: knowledge sharing plays an intermediary role in the relationship between Perceived overqualification and task performance of the team.

H4b: knowledge sharing plays an intermediary role in the relationship between Perceived overqualification and team growth performance.

\section{RESEARCH DESIGN}

\section{A. Research Sample}

In order to ensure the reliability of the questionnaire data, the share links and email to fill in the Commission and issued questionnaire is to illustrate the team or department as the research object, each team at least to ensure that more than 3 people to fill in, no number limit. After the questionnaires were selected according to the following conditions: delete 8 or more consecutive questions answer questionnaire, delete the missing or a multiple-choice questionnaire, the same team the same questionnaire only keep a copy, delete the number less than 3 copies of the questionnaire survey team. After a reasonable selection, the number of valid employees was 578, from 134 teams. Through the Excel software input all valid questionnaire data, and import it into SPSS 22 software for data analysis.

\section{B. Scale Design}

Measuring perceived overqualified from Maynard \& Joseph SPOQ (Scale of Perceived Overqualification Questionnaire) scale of perceived education, experience and knowledge is the ability to exceed job requirements. Knowledge sharing refers to the scale developed by Chennamaneni (2006), and combines relevant literature with the characteristics of the study to make appropriate corrections, including four specific indicators. For team performance, this paper sets up 11 items by referring to the scale developed and revised by Yu Mingli (2003).

\section{DATA ANALYSIS}

\section{A. Reliability Analysis}

The most commonly used method of reliability analysis is the Cronbach 's alpha coefficient, which will be used in this study. It is generally believed that the Cronbach s alpha coefficient is not credible in $0.60-0.65,0.65-0.70$ is the 
smallest acceptable value, and $0.70-0.80$ is very good in reliability, and $0.80-0.90$ is very good in reliability. This study will use SPSS 22 software for reliability analysis, and each scale alpha reliability coefficient is summarized as follows:

TABLE I. CRONBACH'S COEFFICIENT OF EACH SCALE

\begin{tabular}{c|c|c|c|c|c}
\hline Scale & $\begin{array}{c}\text { Perceived } \\
\text { overqualifi } \\
\text { cation }\end{array}$ & $\begin{array}{c}\text { Knowle } \\
\text { dge } \\
\text { sharing }\end{array}$ & $\begin{array}{c}\text { Team } \\
\text { task } \\
\text { perform } \\
\text { ance }\end{array}$ & $\begin{array}{c}\text { Team } \\
\text { growth } \\
\text { perform } \\
\text { ance }\end{array}$ & $\begin{array}{c}\text { Team } \\
\text { perform } \\
\text { ance }\end{array}$ \\
\hline $\begin{array}{c}\text { Cronba } \\
\text { ch's } \alpha\end{array}$ & 0.818 & 0.748 & 0.818 & 0.909 & 0.912 \\
\hline $\begin{array}{c}\text { Numbe } \\
\text { r of } \\
\text { items }\end{array}$ & 9 & 4 & 4 & 7 & 11 \\
\hline
\end{tabular}

As can be seen from the table, the Cronbach, $s$ and alpha coefficients of the dosage table are all above 0.7, which shows that the reliability is very good, and is checked by the reliability test.

\section{B. Validity Analysis}

In validation analysis, the KMO sample is usually measured with the Bart-lett Test of (Sphericity) method, and the measurements are shown in the following table:

TABLE II. KMO VALUES OF EACH SCALE AND BARTLETT SPHERICITY TEST RESULTS

\begin{tabular}{c|c|c|c|c}
\hline \multicolumn{2}{c|}{ Scale } & $\begin{array}{c}\text { Perceived } \\
\text { overquali } \\
\text { fication }\end{array}$ & $\begin{array}{c}\text { Knowledge } \\
\text { sharing }\end{array}$ & $\begin{array}{c}\text { Team } \\
\text { performa } \\
\text { nce }\end{array}$ \\
\hline \multirow{2}{*}{ KMO } & 0.810 & 0.761 & 0.905 \\
\hline \multirow{3}{*}{$\begin{array}{c}\text { Bartlett } \\
\text { sphericity } \\
\text { test }\end{array}$} & $\begin{array}{c}\text { Approximat } \\
\text { e chi square }\end{array}$ & 346.333 & 131.598 & 854.429 \\
\cline { 2 - 5 } & $\begin{array}{c}\text { Freedom( d } \\
\text { f) }\end{array}$ & 36 & 6 & 55 \\
\cline { 2 - 5 } & $\begin{array}{c}\text { Significanc } \\
\text { e(Sig.) }\end{array}$ & .000 & .000 & .000 \\
\hline
\end{tabular}

The qualification is too high to perceive the KMO value of the item and the Bartlett sphericity test result, in which the $\mathrm{KMO}$ value is 0.810 , greater than 0.8 , while the Bartlett sphericity test is remarkable. The KMO measure and Bartlett sphericity test result of knowledge sharing factor analysis, in which the KMO value is 0.761 , greater than 0.7 , shows that it is suitable for factor analysis, and the Bartlett sphericity test is significant. The KMO measure and Bartlett sphericity test result of team performance factor analysis, in which the $\mathrm{KMO}$ value is 0.905 , is greater than 0.9 , is very suitable for factor analysis, and the Bartlett sphericity test is significant.

\section{Regression Analysis}

- Regression analysis of perceived overqualified on team performance

Table III reflects the regression analysis of perceived overqualified and team task performance. Can be seen from the table, with respect to the control variables, explain the perceived overqualified for the team's task performance of delta $\mathrm{R} 2=0.146$, adding the perceived overqualified into the model, the explanatory power of the model increased by $14.6 \%$. At the same time, the non-standardized coefficient of perception of task performance affecting team performance was 0.331 , the standardized coefficient was 0.389 , and the significance level was 0 , which was higher than that of B. It can be inferred that perceived aptitude is positively affecting team task performance, assuming that H1a is supported.

TABLE III. REgRESSION ANALYSIS OF PERCEIVED OVERQuALIFIED AND TEAm TASK PERFORMANCE

\begin{tabular}{|c|c|c|c|c|c|c|c|c|}
\hline & \multicolumn{4}{|c|}{ Model 1} & \multicolumn{4}{|c|}{ Model 2} \\
\hline & B & $\beta$ & Sig & VIF & B & $\beta$ & Sig & VIF \\
\hline \multirow{2}{*}{ Team size } & .04 & .06 & .50 & 1.21 & .02 & .04 & .63 & 1.21 \\
\hline & & 4 & 2 & 1 & 7 & 2 & 2 & 4 \\
\hline \multirow{2}{*}{$\begin{array}{c}\text { Enterprise } \\
\text { scale }\end{array}$} & .03 & .07 & .42 & 1.18 & .04 & .10 & .25 & 1.19 \\
\hline & 6 & 5 & 7 & 9 & 8 & 0 & 1 & 3 \\
\hline \multirow{2}{*}{$\begin{array}{c}\text { Enterprise } \\
\text { nature }\end{array}$} & .10 & .16 & .06 & 1.02 & .06 & .09 & .23 & 1.05 \\
\hline & 5 & 4 & 1 & 0 & 3 & 7 & 5 & 1 \\
\hline \multirow{2}{*}{$\begin{array}{c}\text { perceived } \\
\text { overqualifi } \\
\text { ed }\end{array}$} & & & & & .33 & .38 & .00 & 1.03 \\
\hline & & & & & 1 & 9 & 0 & 3 \\
\hline $\mathrm{R} 2$ & \multicolumn{4}{|c|}{.037} & \multicolumn{4}{|c|}{.183} \\
\hline $\begin{array}{c}\text { Adjusted } \\
\text { R2 }\end{array}$ & \multicolumn{4}{|c|}{.015} & \multicolumn{4}{|c|}{.158} \\
\hline$\Delta \mathrm{R} 2$ & \multicolumn{4}{|c|}{.037} & \multicolumn{4}{|c|}{.146} \\
\hline
\end{tabular}

Table IV reflects the regression analysis of the perception of excessive quality and the growth performance of the team. Can be seen from the table, with respect to the control variables, explain the perceived overqualified for the team's growth performance of delta $\mathrm{R} 2=0.041$, adding the perceived overqualified into the model, the explanatory power of the model increased by $4.1 \%$. At the same time, the nonstandardized coefficient $B$ value of perceived overqualified on team growth performance is 0.177 , the standardized coefficient of beta $0.207, p=0.017$. From this we can conclude that the perceived overqualified has no significant influence on the growth performance of the team, assuming that $\mathrm{H} 1 \mathrm{~b}$ is not valid.

TABLE IV. REGRESSION ANALYSIS OF PERCEIVED OVERQuALIFIED ON TEAM GROWTH PERFORMANCE

\begin{tabular}{|c|c|c|c|c|c|c|c|c|}
\hline & \multicolumn{4}{|c|}{ Model 1} & \multicolumn{4}{|c|}{ Model 2} \\
\hline & B & $\beta$ & $\begin{array}{l}\mathrm{Si} \\
\mathrm{g} .\end{array}$ & $\begin{array}{l}\mathrm{VI} \\
\mathrm{F}\end{array}$ & B & $\beta$ & Sig. & VIF \\
\hline Team size & $\begin{array}{c}.09 \\
1\end{array}$ & $\begin{array}{c}.14 \\
0\end{array}$ & $\begin{array}{c}.14 \\
1\end{array}$ & $\begin{array}{l}1.2 \\
11\end{array}$ & $\begin{array}{c}.08 \\
4\end{array}$ & .128 & .169 & $\begin{array}{c}1.21 \\
4\end{array}$ \\
\hline $\begin{array}{c}\text { Enterprise } \\
\text { scale }\end{array}$ & $\begin{array}{c}.01 \\
9\end{array}$ & $\begin{array}{c}.03 \\
9\end{array}$ & $\begin{array}{c}.67 \\
9\end{array}$ & $\begin{array}{l}1.1 \\
89\end{array}$ & $\begin{array}{c}.02 \\
5\end{array}$ & .052 & .570 & $\begin{array}{c}1.19 \\
3\end{array}$ \\
\hline $\begin{array}{c}\text { Enterprise } \\
\text { nature }\end{array}$ & $\begin{array}{c}.09 \\
5\end{array}$ & $\begin{array}{c}.14 \\
7\end{array}$ & $\begin{array}{c}.09 \\
2\end{array}$ & $\begin{array}{l}1.0 \\
20\end{array}$ & $\begin{array}{c}.07 \\
2\end{array}$ & .112 & .198 & $\begin{array}{c}1.05 \\
1\end{array}$ \\
\hline $\begin{array}{c}\text { perceived } \\
\text { overqualifi } \\
\text { ed }\end{array}$ & & & & & $\begin{array}{l}.17 \\
7\end{array}$ & .207 & .017 & $\begin{array}{c}1.03 \\
3\end{array}$ \\
\hline $\mathrm{R} 2$ & \multicolumn{4}{|c|}{.041} & \multicolumn{4}{|c|}{.083} \\
\hline $\begin{array}{c}\text { Adjusted } \\
\text { R2 }\end{array}$ & \multicolumn{4}{|c|}{.019} & \multicolumn{4}{|c|}{.054} \\
\hline$\Delta \mathrm{R} 2$ & \multicolumn{4}{|c|}{.041} & \multicolumn{4}{|c|}{.041} \\
\hline
\end{tabular}

- Regression analysis of perceived overqualified on knowledge sharing

Table $\mathrm{V}$ reflects the regression analysis situation of perceived overqualified on knowledge sharing. As can be 
seen from the table, relative to the control variables, the explanatory power of perceived overqualified on knowledge sharing is significantly enhanced. At the same time, the non standardized coefficient of knowledge sharing that affects team knowledge sharing is 0.362 , and the standardized coefficient beta is $0.368, \mathrm{~B}, \mathrm{p}=0.000$. From this we can infer that the perceived overqualified positively influence knowledge sharing, assuming that $\mathrm{H} 2$ is established.

TABLE V. REgRESSION ANALYSIS OF PERCEIVED OVERQUALIFIED ON TEAM KNOWLEDGE SHARING

\begin{tabular}{|c|c|c|c|c|c|c|c|c|}
\hline & \multicolumn{4}{|c|}{ Model 1} & \multicolumn{4}{|c|}{ Model 2} \\
\hline & B & $\beta$ & Sig & VIF & B & $\beta$ & Sig & VIF \\
\hline Team size & .063 & $\begin{array}{c}.09 \\
1\end{array}$ & $\begin{array}{c}.34 \\
3\end{array}$ & $\begin{array}{c}1.21 \\
1\end{array}$ & .060 & $\begin{array}{c}.08 \\
7\end{array}$ & $\begin{array}{c}.36 \\
5\end{array}$ & $\begin{array}{c}1.21 \\
4\end{array}$ \\
\hline $\begin{array}{l}\text { Enterprise } \\
\text { scale }\end{array}$ & .048 & $\begin{array}{c}.09 \\
4\end{array}$ & $\begin{array}{c}.32 \\
3\end{array}$ & $\begin{array}{c}1.18 \\
9\end{array}$ & $\begin{array}{c}.005 \\
0\end{array}$ & $\begin{array}{c}.09 \\
8\end{array}$ & $\begin{array}{c}.30 \\
2\end{array}$ & $\begin{array}{c}1.19 \\
3\end{array}$ \\
\hline $\begin{array}{c}\text { Enterprise } \\
\text { nature }\end{array}$ & $\begin{array}{c}.001 \\
4\end{array}$ & $\begin{array}{c}.02 \\
1\end{array}$ & $\begin{array}{c}.81 \\
1\end{array}$ & $\begin{array}{c}1.02 \\
0\end{array}$ & .006 & $\begin{array}{c}.00 \\
9\end{array}$ & $\begin{array}{c}.71 \\
7\end{array}$ & $\begin{array}{c}1.05 \\
1\end{array}$ \\
\hline $\begin{array}{l}\text { perceived } \\
\text { overqualifi } \\
\text { ed }\end{array}$ & & & & & .362 & $\begin{array}{c}.36 \\
8\end{array}$ & $\begin{array}{c}.00 \\
0\end{array}$ & $\begin{array}{c}1.03 \\
3\end{array}$ \\
\hline R2 & \multicolumn{4}{|c|}{.024} & \multicolumn{4}{|c|}{.028} \\
\hline $\begin{array}{l}\text { Adjusted } \\
\text { R2 }\end{array}$ & \multicolumn{4}{|c|}{.001} & \multicolumn{4}{|c|}{-.002} \\
\hline$\Delta \mathrm{R} 2$ & \multicolumn{4}{|c|}{.024} & \multicolumn{4}{|c|}{.005} \\
\hline
\end{tabular}

- Regression analysis of knowledge sharing on team performance

Table VI reflects the regression analysis of knowledge sharing on team task performance. Can be seen from the table, with respect to the control variables, explain the perceived overqualified for the team's task performance of delta $\mathrm{R} 2=0.216$, joining knowledge sharing into the model, the explanatory power of the model increased by $21.6 \%$. At the same time, knowledge sharing influences the task performance of teams. The coefficient of B is 0.177 , and the standardized factor is $0.207, p=0.017$. From this we can conclude that the perceived overqualified positively influences team task performance, assuming that $\mathrm{H3a}$ is established.

TABLE VI. REgRESSION ANALYSIS OF KNOWLEDGE SHARING ON TEAM TASK PERFORMANCE

\begin{tabular}{|c|c|c|c|c|c|c|c|c|}
\hline & \multicolumn{4}{|c|}{ Model 1} & \multicolumn{4}{|c|}{ Model 2} \\
\hline & B & $\beta$ & Sig. & VIF & B & $\beta$ & Sig. & VIF \\
\hline Team size & .04 & .06 & .50 & 1.21 & .01 & .02 & .80 & 1.21 \\
\hline & 1 & 4 & 2 & 1 & 4 & 1 & 2 & 9 \\
\hline Enterpris & .03 & .07 & .42 & 1.18 & .01 & .03 & .71 & 1.19 \\
\hline e scale & 6 & 5 & 7 & 9 & 5 & 1 & 3 & 8 \\
\hline Enterpris & .10 & .16 & .06 & 1.02 & .09 & .15 & .04 & 1.02 \\
\hline e nature & 5 & 4 & 1 & 0 & 9 & 4 & 7 & 1 \\
\hline knowledg & & & & & .44 & .47 & .00 & 1.02 \\
\hline e sharing & & & & & 1 & 0 & 0 & 4 \\
\hline R2 & \multicolumn{4}{|c|}{.037} & \multicolumn{4}{|c|}{253} \\
\hline $\begin{array}{l}\text { Adjusted } \\
\text { R2 }\end{array}$ & \multicolumn{4}{|c|}{015} & \multicolumn{4}{|c|}{.230} \\
\hline$\Delta \mathrm{R} 2$ & \multicolumn{4}{|c|}{.037} & \multicolumn{4}{|c|}{.216} \\
\hline
\end{tabular}

Table VII reflects the regression analysis of knowledge sharing on team growth performance. As can be seen from the table, relative to the control variables, knowledge sharing increases the explanatory power of the team's growth performance. $\mathrm{R} 2=0.041$, that is, after adding knowledge sharing into the model, the explanatory power of the model has increased by $4.1 \%$. At the same time, the nonstandardized coefficient B value of perceived overqualified on team growth performance is 0.639 , the standardized coefficient of beta $0.677, p=0.000$. It can be inferred that knowledge sharing positively influences team growth performance, assuming that $\mathrm{H} 3 \mathrm{~b}$ is established.

TABLE VII. REgRESSION ANALYSIS OF KNOWLEDGE SHARING ON TEAM GROWTH PERFORMANCE

\begin{tabular}{|c|c|c|c|c|c|c|c|c|}
\hline & \multicolumn{4}{|c|}{ Model 1} & \multicolumn{4}{|c|}{ Model 2} \\
\hline & B & $\beta$ & Sig & VIF & B & $\beta$ & Sig & VIF \\
\hline Team size & $\begin{array}{c}.09 \\
1\end{array}$ & $\begin{array}{c}.14 \\
0\end{array}$ & $\begin{array}{c}.14 \\
1\end{array}$ & $\begin{array}{c}1.21 \\
1\end{array}$ & .051 & .079 & $\begin{array}{c}.26 \\
1\end{array}$ & $\begin{array}{c}1.21 \\
9\end{array}$ \\
\hline $\begin{array}{c}\text { Enterprise } \\
\text { scale }\end{array}$ & $\begin{array}{c}.01 \\
9 \\
\end{array}$ & $\begin{array}{c}.03 \\
9 \\
\end{array}$ & $\begin{array}{c}.67 \\
9 \\
\end{array}$ & $\begin{array}{c}1.18 \\
9\end{array}$ & $\begin{array}{c}-.01 \\
2 \\
\end{array}$ & $\begin{array}{c}-.02 \\
5 \\
\end{array}$ & $\begin{array}{l}.72 \\
2 \\
\end{array}$ & $\begin{array}{c}1.19 \\
8\end{array}$ \\
\hline $\begin{array}{c}\text { Enterprise } \\
\text { nature }\end{array}$ & $\begin{array}{c}.09 \\
5\end{array}$ & $\begin{array}{c}.14 \\
7 \\
\end{array}$ & $\begin{array}{c}.09 \\
2\end{array}$ & $\begin{array}{c}1.02 \\
0\end{array}$ & .086 & .133 & $\begin{array}{c}.03 \\
9 \\
\end{array}$ & $\begin{array}{c}1.02 \\
1\end{array}$ \\
\hline $\begin{array}{l}\text { perceived } \\
\text { overqualifi } \\
\text { ed }\end{array}$ & & & & & .639 & .677 & $\begin{array}{c}.00 \\
0\end{array}$ & $\begin{array}{c}1.02 \\
4\end{array}$ \\
\hline R2 & \multicolumn{4}{|c|}{.041} & \multicolumn{4}{|c|}{.083} \\
\hline $\begin{array}{c}\text { Adjusted } \\
\text { R2 } \\
\end{array}$ & \multicolumn{4}{|c|}{.019} & \multicolumn{4}{|c|}{.054} \\
\hline$\Delta \mathrm{R} 2$ & \multicolumn{4}{|c|}{.041} & \multicolumn{4}{|c|}{.041} \\
\hline
\end{tabular}

- Mediating effect test

In this paper, we will use the method of testing the regression coefficient in turn to test the mediating effect. The above regression analysis showed that perceived overqualified had a significant influence on team knowledge sharing and task performance, and it was positively related to team performance, namely $\mathrm{Y}=\mathrm{cX}+\mathrm{e} 1$ in equation $\mathrm{C}$ (0.389) and $\mathrm{M}=\mathrm{aX},+\mathrm{e} 2$ a $(0.368)$ was significant, so knowledge sharing satisfies the first two conditions the mediating effect between perceived overqualified and task performance of can be a significant test of the equation $\mathrm{Y}=$ $\mathrm{C}^{\prime} \mathrm{X}+\mathrm{bM}+\mathrm{e} 3 \mathrm{C}^{\prime}$ and $\mathrm{B} \mathrm{H} 4 \mathrm{a}$, to verify the hypothesis. The hypothesis of $\mathrm{H} 4 \mathrm{~b}$, because of the perceived overqualified did not significantly affect the team's growth performance, namely $\mathrm{Y}=\mathrm{cX}+\mathrm{e} 1 \mathrm{C}$ equation is not significant, do not satisfy the first condition of the mediating effect of knowledge sharing, can not be carried out on the mediating effect of perceived overqualified and growth performance relationship, assuming $\mathrm{H} 4 \mathrm{~b}$ is not established.

Next, we get the perceived overqualified, knowledge sharing and control variable into regression equation of the team task performance and the regression results as follows. It can be seen that when knowledge sharing is introduced into the regression model of perceived task performance, $\mathrm{R} 2=0.340$ shows that adding knowledge sharing variables can better explain the task performance of the team. In the equations $\mathrm{Y}=, \mathrm{C}^{\prime}, \mathrm{X},+\mathrm{bM},+\mathrm{e} 3$, the $\mathrm{b}$ value is 0.446 , and the significance is $\mathrm{p}<0.000$. Combining $\mathrm{M},=\mathrm{aX},+\mathrm{e} 2$ and $\mathrm{Y}=, \mathrm{C}^{\prime}$, $\mathrm{X},+\mathrm{bM}$, and $+\mathrm{e} 3$, the two equations show that both a and $\mathrm{B}$ are very significant, indicating that knowledge sharing plays an intermediary role in perceived aptitude and task performance of the team. $C^{\prime}=0.358$, the significant level is 0 , so it is a part of the intermediary role, influence of perceived 
overqualified on team task performance is not completely through the mediating role of knowledge sharing to achieve the effect of perceived overqualified on team task performance has a direct effect. Suppose $\mathrm{H} 4 \mathrm{a}$ is founded.

TABLE VIII. TABle ViI MEDiating EFFECTS OF KNOWLEDGE SHARING ON PERCEIVED COMPETENCE AND TASK PERFORMANCE OF TEAMS

\begin{tabular}{|c|c|c|c|c|c|c|c|}
\hline & \multicolumn{3}{|c|}{ Model 1} & \multicolumn{4}{|c|}{ Model 2} \\
\hline & B & $\beta$ & VIF & B & $\beta$ & Sig. & VIF \\
\hline Team size & $\begin{array}{c}.0 \\
14\end{array}$ & $\begin{array}{l}.0 \\
21\end{array}$ & $\begin{array}{c}1.21 \\
9\end{array}$ & .002 & $\begin{array}{l}.0 \\
03\end{array}$ & $\begin{array}{c}.96 \\
6\end{array}$ & 1.222 \\
\hline $\begin{array}{l}\text { Enterprise } \\
\text { scale }\end{array}$ & $\begin{array}{c}.0 \\
15\end{array}$ & $\begin{array}{l}.0 \\
31\end{array}$ & $\begin{array}{c}1.19 \\
8\end{array}$ & .027 & $\begin{array}{l}.0 \\
56\end{array}$ & $\begin{array}{c}.46 \\
2\end{array}$ & 1.203 \\
\hline $\begin{array}{c}\text { Enterprise } \\
\text { nature }\end{array}$ & $\begin{array}{l}.0 \\
99\end{array}$ & $\begin{array}{l}.1 \\
54\end{array}$ & $\begin{array}{c}1.02 \\
1\end{array}$ & .060 & $\begin{array}{l}.0 \\
93\end{array}$ & $\begin{array}{l}.19 \\
5\end{array}$ & 1.051 \\
\hline $\begin{array}{c}\text { perceived } \\
\text { overqualif } \\
\text { ied } \\
\end{array}$ & & & & .305 & $\begin{array}{c}.3 \\
58\end{array}$ & $\begin{array}{c}.00 \\
0\end{array}$ & 1.038 \\
\hline $\begin{array}{l}\text { knowledg } \\
\text { e sharing }\end{array}$ & $\begin{array}{r}.4 \\
41 \\
\end{array}$ & $\begin{array}{c}.4 \\
70 \\
\end{array}$ & $\begin{array}{c}1.02 \\
4 \\
\end{array}$ & .418 & $\begin{array}{c}.4 \\
46 \\
\end{array}$ & $\begin{array}{c}.00 \\
0 \\
\end{array}$ & 1.029 \\
\hline R2 & & & & & & 77 & \\
\hline $\begin{array}{c}\text { Adjusted } \\
\text { R2 }\end{array}$ & & & & & & 52 & \\
\hline$\Delta \mathrm{R} 2$ & & & & & & 40 & \\
\hline
\end{tabular}

V.CONCLUSIONS

First of all, this study demonstrates that perceived overqualified has a significant positive impact on team task performance. Although from the justice theory and social exchange theory, perceived overqualified employees have higher expectations, but the current job is not challenging enough or lack of corresponding development opportunity, the work of the staff satisfaction level will be reduced, thus losing enthusiasm, do not pay to complete tasks in team work in. But, on the other hand, perceived overqualified employees in order to get rid of their relative deprivation situation, they may be more hard at work, plus this will exceed the requirements of education, experience, knowledge and ability, and ultimately enhance the possibility of team performance is very large.

Secondly, the results show that perceived overqualified has no significant influence on team growth performance. This is probably because if most of the members of the team are aware of their qualifications are too high, so the team target relatively difficult to display their level, more do not talk to stimulate their potential and team members in this case learning ability and willingness to learn job skills can't be promoted, in does not stop before the state space, greatly reduce the team growth.

Perceived overqualified has positive predictive effect on knowledge sharing. Although the qualification of high staff did not get the reuse in the organization, but for the need to demonstrate their own value and communication, they will still express more than the ability to adapt to knowledge sharing behavior, to maximize their advantages, offset ability is negative sense of relative deprivation.

Finally, knowledge sharing has a mediating effect on the perceived overqualified and team task performance, namely perceived overqualified through positive impact on knowledge sharing so as to enhance the team's task performance, at the same time, the perceived overqualified predict team task performance directly.

\section{REFERENCES}

[1] Maynard D C, Parfyonova N M. Perceived over qualification and withdrawal behaviors: Examining the roles of job attitudes and work values [J]. Journal of Occupational and Organizational Psychology, 2013, 86(3):435-455.

[2] Luksyte A, Spitzmueller C, Maynard D C. Why do overqualified incumbents deviate? Examining multiple mediators. [J]. Journal of Occupational Health Psychology, 2011, 16(3):279-96.

[3] Bolino M C, Feldman D C. The Antecedents and Consequences of Underemployment among Expatriates [J]. Journal of Organizational Behavior, 2000, 21(8):889-911.

[4] Holtom B C, Lee T W, Tidd S T. The relationship between work status congruence and work-related attitudes and behaviors [J]. Journal of Applied Psychology, 2002, 87(5):903.

[5] Erdogan B, Bauer T N. Perceived over qualification and its outcomes: The moderating role of empowerment. [J]. Journal of Applied Psychology, 2009, 94(2):557-565.

[6] Liu Ruirui. Employee qualification, perceived content structure and related research [D]. Henan University, 2011.

[7] Li Xianan. Research on the relationship between knowledge sharing and team performance based on knowledge sharing [D]. Zhejiang SciTech University, 2013 